\title{
Stylogyne (Myrsinaceae) no estado do Rio de JANeiro, BRASIL ${ }^{1}$
}

\author{
Tatiana Tavares Carrijo ${ }^{1,3,4}$ \& Maria de Fátima Freitas ${ }^{2}$
}

\begin{abstract}
Resumo
(Stylogyne (Myrsinaceae) no estado do Rio de Janeiro, Brasil) Oito espécies de Stylogyne ocorrem no estado do Rio de Janeiro, das quais $S$. depauperata, S. lhotzkiana, S. sellowiana e S. sordida são endêmicas. As flores pistiladas de $S$. lhotzkiana e bissexuais de $S$. sellowiana são descritas pela primeira vez. Cinco espécies são ilustradas pela primeira vez. São apresentados chave para identificação, comentários sobre afinidades, distribuição geográfica e ecologia das espécies. A Serra do Mar se destaca como importante centro de diversidade do gênero no estado do Rio de Janeiro, sendo os contrafortes da Serra dos Órgãos e do Maciço do Tinguá, as áreas com maior representatividade de táxons.
\end{abstract}

Palavras-chave: flora, taxonomia, Serra do Mar, Floresta Pluvial Atlântica.

\section{Abstract}

(Stylogyne (Myrsinaceae) of the state of Rio de Janeiro, Brazil) Eight species of Stylogyne occur in Rio de Janeiro state, S. depauperata Mez, S. lhotzkiana, S. sellowiana and S. sordida being endemics. The pistillate flowers of S. lhotzkiana and the bisexual ones of S. sellowiana are described for the first time. Five species are illustrated for the first time. Identification key, and commentaries about affinities, distribution and ecology of the species are provided. In Rio de Janeiro state, the Serra do Mar presents the greatest diversity of Stylogyne species, in which the Serra dos Órgãos and Tinguá groups of mountains show the larger number of taxa.

Key words: flora, taxonomy, Serra do Mar, Pluvial Atlantic Forest.

\section{INTRODUÇÃO}

O gênero Stylogyne A.DC.é exclusivamente neotropical e possui entre 60-70 espécies (Pipoly \& Ricketson 2000) dióicas, androdióicas, polígamas e bissexuais (Lundell 1971; Pipoly 1989; Ricketson \& Pipoly 1997), predominantes na América do Sul (Ricketson \& Pipoly 2003). $\mathrm{Na}$ única revisão realizada para o gênero (Mez 1902) foram citadas 28 espécies para o Brasil.

Stylogyne apresenta maior afinidade com os gêneros Geissanthus Hook.f. e Ardisia Sw. De Geissanthus, Stylogyne pode ser diferenciado pelas sépalas com 4-5 lobos abertos no botão, e pela corola de estivação contorta (Ricketson \& Pipoly 1997). De Ardisia, Stylogyne tem sido tradicionalmente distinto pela corola de estivação contorta e pelos óvulos unisseriados, raramente bisseriados (Ricketson \& Pipoly 1997). Bernacci \& Jung-Mendaçolli (2000) discordaram da viabilidade destes caracteres ao analisar as espécies de Stylogyne ocorrentes na Região
Sudeste do Brasil, e sinonimizaram os táxons estudados a Ardisia. Em função da condição parafilética de Ardisia (Ståhl 1996) e do conhecimento precário de Stylogyne, são necessários estudos mais detalhados para que se compreenda a complexa relação entre estes gêneros.

Floras locais ou regionais e listagens de espécies realizadas para os estados do Amazonas (Ribeiro et al. 1999), São Paulo (Jung-Mendaçolli \& Bernacci 1997; JungMendaçolli et al. 2005), Minas Gerais (Oliveira-Filho 2006) e Rio de Janeiro (JungMendaçolli \& Bernacci 2001) têm corroborado a forte tendência a endemismos e ocupação preferencial das espécies de Stylogyne em áreas em bom estado de conservação, como sinalizado para os táxons da América do Sul (Pipoly 1991; Pipoly 1999; Pipoly \& Ricketson 1999; Pipoly \& Ricketson 2000) e da América Central (Ricketson \& Pipoly 2003). Esses

Artigo recebido em 08/2007. Aceito para publicação em 4/2008.

${ }^{1}$ Parte da Dissertação de Mestrado apresentada ao Programa de Pós-Graduação em Botânica da Escola Nacional de Botânica Tropical/Instituto de Pesquisas Jardim Botânico do Rio de Janeiro.

${ }^{2}$ Instituto de Pesquisas Jardim Botânico do Rio de Janeiro, R. Pacheco Leão 915, 22460-030, Rio de Janeiro, RJ, Brasil. ${ }^{3}$ Universidade Federal do Espírito Santo, Departamento de Biologia, CECENS, Rua Alto Universitário s/n, Guararema, 29500-000, Alegre, ES, Brasil

${ }^{4}$ Autor para correspondência: tcarrijo@gmail.com 
dados são preocupantes em relação à conservação das espécies no atual contexto de degradação da Floresta Pluvial Atlântica, porque alguns representantes de Stylogyne são restritos a este bioma.

Este trabalho dá início ao estudo do gênero Stylogyne no Brasil. São fornecidas descrições, ilustrações inéditas e chave de identificação, além de comentários sobre a taxonomia, distribuição geográfica e ambiente preferencial das espécies do estado do Rio de Janeiro.

\section{Material e Métodos}

A listagem preliminar dos binômios de Stylogyne citados para o estado do Rio de Janeiro foi realizada a partir das obras clássicas de De Candolle (1837, 1841, 1844), Miquel (1856) e Mez (1902), e floras locais realizadas para Myrsinaceae na Região Sudeste (Jung-Mendaçolli \& Bernacci 1997; Jung-Mendaçolli \& Bernacci 2001; Jung-Mendaçolli et al. 2005).

Tipos ou fotografias dos tipos obtidas dos herbários de Paris (P), Field Museum (F) e New York Botanical Garden (NY) foram utilizados como auxiliares a identificação das espécies. Foram examinadas as coleções dos herbários GUA, HB, R, RB, RFA (acrônimos segundo Holmgren \& Holmgren 2006). Exsicatas procedentes de herbários do estado de São Paulo (IAC, SP, SPSF, UEC) foram analisadas para verificação dos limites de variação morfológica de algumas espécies e, quando pertinente, são citadas como material adicional.

As espécies estão apresentadas segundo a circunscrição de Mez (1902). A chave de identificação e as descrições do gênero e das espécies foram realizadas com base nos materiais procedentes do estado do Rio de Janeiro.

Nas descrições morfológicas foram seguidos os conceitos e terminologias de Radford et al. (1974). Para caracterização da arquitetura foliar foi seguido o conceito adotado por Lopes (1999), pelo qual a nervação campto-broquidódroma é definida da seguinte forma: "nervura principal mais espessa que as demais nervuras, da qual partem obliquamente nervuras mais tênues que formam grandes arcos na lateral das folhas, acima dos quais se inicia a formação de arcos menores; as nervuras terciárias são anastomosadas formando retículos". A caracterização das regiões fitoecológicas e fitofisionomias segue o Manual Técnico da Vegetação Brasileira/IBGE (1992).

\section{Resultados e Discussão}

Stylogyne A.DC., Ann. Sci. Nat., Bot., ser. 2, 16: 91.1841.

Arbustos dióicos, androdióicos, polígamos ou bissexuais, 1,5-5(10) m, cespitosos ou unicaules e dicotômicos pouco acima da base, ramos glabros, raramente pilosos nas porções jovens e gema terminal. Folhas pecioladas, lâmina com estruturas secretoras internas translúcidas aparentes ou não, glabras. Inflorescências estritamente terminais, ou terminais e subterminais, ou subterminais e axilares, axilares e ramifloras, ou estritamente axilares, paniculado-corimbosas expandidas ou compactadas, corimbosas ou fasciculadas, glabras. Flores bissexuais ou unissexuais, pediceladas, 4 ou 5-meras, glabras, cálice e corola contorto-dextrorsos, corola campanulada, actinomorfa a ligeiramente zigomorfa, lobos eretos ou reflexos a revolutos. Estames livres entre si, retos ou torcidos no botão, ultrapassando ou não o pistilo nas flores estaminadas, subiguais ao pistilo nas flores bissexuais e pistiladas, raro ultrapassando, filetes adnatos à base do tubo da corola ou um pouco acima, anteras elíptico-lanceoladas, lanceoladas, oblongo-elípticas e oblongo-lineares estaminadas, dorsifixas, introrsas, deiscentes por longas fendas laterais ou fendas laterais curtas com ápice triangular dilatado. Pistilo com ovário ovóide ou ampuliforme, 3-5 óvulos unisseriados, estilete cilíndrico, estigma truncado, capitulado, capitado, discóide ou 3-lobado, papiloso ou não; pistilódio cônico ou ausente nas flores estaminadas. Fruto drupáceo, monospérmico, cálice e estilete persistentes, pericarpo ligeiramente carnoso, endosperma ósseo ou crustáceo, perfurado, embrião transverso, filiforme.

No estado do Rio de Janeiro foram encontradas Stylogyne sp., S. depauperata Mez, S. laevigata, S. leptantha, S. lhotzkiana, S. pauciflora Mez, S. sellowiana e S. sordida. 


\section{Chave para as espécies de Stylogyne no estado do Rio de Janeiro}

1. Inflorescências estritamente terminais, ou terminais e ramifloras, ou terminais e subterminais (nunca estritamente axilares ou axilares e ramifloras); flores 5-meras ou 4-meras.

2. Inflorescências corimbosas; flores 4-meras; anteras deiscentes por fendas com ápice triangular dilatado

2'. Inflorescências paniculadas; flores 5-meras; anteras deiscentes por fendas longitudinais.

3. Pétalas eretas com pontuações glandulares elípticas e brunas, estigma discóide

5. S. lhotzkiana

3'. Pétalas deflexas, com pontuações glandulares elípticas e circulares nigrescentes, estigma capitado.

4. Inflorescências terminais, 9-11,5×8-12 cm; pétalas oblongo-elípticas de ápice agudo

3. S. laevigata

4'. Inflorescências terminais e subterminais, 5-6×2-2,5 cm; pétalas oblongas de ápice arredondado a truncado emarginado 4. S. leptantha

1'. Inflorescências estritamente axilares, ou subterminais e axilares, ou axilares e ramifloras; flores estritamente 4-meras.

5. Folhas broquidódromas, inflorescências subterminais e axilares 1. Stylogyne sp.

5'. Folhas campto-broquidódromas; inflorescências axilares ou axilares e ramifloras.

6. Inflorescências fasciculadas; pétalas simétricas, não pontuadas 7. S. sordida

6'. Inflorescências corimbosas; pétalas assimétricas ou simétricas, densamente pontuadas.

7. Pecíolos 6-9 mm compr.; margem da lâmina foliar inteira; filetes adnatos acima da base do tubo da corola 2. S. depauperata

7'. Pecíolos 9-12 mm compr.; margem da lâmina foliar serrilhada; filetes adnatos à base do tubo da corola 8. S. sellowiana

\section{Stylogyne sp.}

Arbustos, 4-5 m alt. Ramos cilíndricos, 2,7-3,4 mm diâm., glabros. Pecíolos canaliculados, 8-12 mm compr., 1,9-2,8(3,2) diâm., com pontuações laranjadas e nigrescentes nas margens; lâmina foliar cartácea, oblongo-elíptica, 15,5$21 \times 7-8 \mathrm{~cm}$, base atenuada, ápice agudo a apiculado, nervação broquidódroma, margem inteira, revoluta. Inflorescências subterminais e axilares, corimbosas, $2-2,5 \mathrm{~cm}$ compr., bipenadas ou tripenadas. Flores estaminadas 4-meras, 3,8$4 \mathrm{~mm}$ compr.; pedicelos 2-3,5 mm compr., glabros; brácteas cartáceas, lanceoladas, 0,8-0,9 mm compr., margem inteira, fimbriada no ápice, com pontuações aparentes ou não; cálice 1,8-2 mm compr., sépalas cartáceas, ovadas, 1,2-1,5 $\times 1,3-1,6 \mathrm{~mm}$, fusionadas na base, lobos eretos, com pontuações glandulares pouco aparentes, ápice subtriangular, margem inteira, hialina; corola campanulada, pétalas cartáceas, elípticas, 3,7$4,4 \mathrm{~mm}$ compr., fusionadas $0,9-1 \mathrm{~mm}$ compr., com pontuações alaranjadas inconspícuas, lobos 3,6-3,9 × 1,5-1,9 mm, assimétricos, deflexos, ápice agudo e ligeiramente acuminado, margem inteira, uniforme; estames 2,9-3,3 mm compr., filetes ligulados, 1-1,2 mm compr., adnatos à base do tubo da corola, anteras oblongo-elípticas, 2,4$2,6 \times 0,8-1 \mathrm{~mm}$, deiscentes por fendas laterais com ápice dilatado, base cordada, ápice obtuso, apiculado; pistilódio vestigial (cônico) ou ausente. Flores bissexuais ou pistiladas não vistas. Fruto esférico, 6-6,4 × 5,5-6 mm, pericarpo com pontuações lineares nigrescentes.

Material analisado: BRASIL. RIO DE JANEIRO: Divisa Rio-São Paulo, 22.XI.1990, fl., M. A. N. Coelho 658 (RB); Paraty, APA do Cairuçu, 23.VIII.1995, fr., A. Castelar 19 (RB).

Material adicional: BRASIL. SÃO PAULO: Caraguatatuba, Parque Estadual da Serra do Mar, 20.XI.2000, fl., I. Cordeiro 2360 (SPF, SPSF).

Distribuição geográfica e habitat: restrita aos estados de Rio de Janeiro e São Paulo. No estado do Rio de Janeiro ocorre estritamente na região Sul Fluminense (Fig. 3), no município de Paraty. Habita Floresta Ombrófila Densa Submontana (140 m s.m.). 
Dados fenológicos: coletada com flores no mês de novembro e com frutos de agosto.

Stylogyne sp. mostra afinidade com $S$. depauperata, mas difere pelas folhas com nervação broquidódroma (não camptobroquidódroma), sépalas com ápice agudo (não arredondado), pétalas assimétricas (não simétricas), com ápice agudo (não arredondado) e margem inteira, uniforme (não irregular, hialina).

Esta espécie foi tratada por JungMendaçolli \& Bernacci (1997) sob o binômio Stylogyne depauperata, e posteriormente combinada a Ardisia depauperata (Mez) Bernacci \& Jung-Mendaçolli (Bernacci \& Jung-Mendaçolli 2000), tratamento mantido na Flora da APA do Cairuçu (2001) e na Flora do Estado de São Paulo (Jung-Mendaçolli et al. 2005). A análise de um dos síntipos depositado no herbário R e de materiais da coleção geral dos herbários R e RB possibilitaram a distinção dessas espécies. Futuras análises poderão indicar se este é um novo táxon.

2. Stylogyne depauperata Mez in Engl. Das Pflanzenreich 4(236): 277. $1902 . \quad$ Fig. 1

Arbustos ou árvores, 5-6 m alt. Ramos cilíndricos, 2,6-3,9 mm diâm., glabros. Pecíolos canaliculados, 6-9 mm compr., 2,2-2,8 mm diâm., glabros; lâmina foliar cartácea, oblongoelíptica a elíptico-obovada, 15,6-16,2(22,5)× $6,2-7,2(8,7) \mathrm{cm}$, base arredondada a aguda, ápice arredondado, agudo ou ligeiramente acuminado, nervação campto-broquidódroma, margem inteira, revoluta. Inflorescências axilares e ramifloras, corimbosas, 11,3-13,5(15) mm compr., bipenadas. Flores bissexuais e unissexuais (estaminadas), 4-meras, 3,4-4 mm compr.; pedicelos cilíndricos, 2,8-3,2 mm compr., glabros; brácteas cartáceas, lanceoladas, 0,7$0,9 \mathrm{~mm}$ compr., com pontuações cilíndricas e elípticas nigrescentes; cálice 1,4-1,5 mm compr., com pontuações nigrescentes inconspícuas, sépalas cartáceas, ovadas, 1-1,2×0,9-1 mm, fusionadas na base, lobos eretos, ápice largamente arredondado, superfície rugosa, margem distintamente hialina, levemente irregular; corola campanulada, pétalas cartáceas, elípticas, 3,6-4 mm compr., fusionada 0,8-1 mm compr., com densas pontuações elípticas e lineares nigrescentes, lobos 2,7-3 × 1,6-1,7 mm, simétricos, ápice arredondado, margem distintamente hialina, levemente irregular; flores estaminadas com estames 2,5-2,9 mm compr., filetes ligulados, $1,2-1,5 \mathrm{~mm}$ compr., adnatos ca. $1,2 \mathrm{~mm}$ acima da base do tubo da corola; anteras elípticolanceoladas, 2,0-2,3 ×0,8-1,0 mm, deiscentes por fendas laterais com ápice dilatado, base cordada, ápice obtuso a agudo, apiculado; pistilódio 1,4-1,7 mm compr., cônico; flores bissexuais com estames $1,8-2,0 \mathrm{~mm}$ compr., anteras $1,5-1,9 \times 0,5-0,8 \mathrm{~mm}$, pistilo $2,5-2,9$ $\mathrm{mm}$ compr., ovário ampuliforme, ca. $0,9 \times 0,5$ mm, 4-5 óvulos unisseriados, estilete cilíndrico, 1,3-1,6 mm compr., estigma capitado. Fruto esferoidal, ca. 7,3 $\times 7,1 \mathrm{~mm}$, pericarpo com densas pontuações lineares nigrescentes.

Material selecionado: BRASIL. RIO DE JANEIRO: Guapimirim, Serra dos Órgãos, 20.I.1975, fl., $P$. Occhioni 6871 (RFA); Rio de Janeiro, próximo à Tijuca, 29.XII.1869, fl., A. F. Glaziou 4073 (R); Parque Nacional da Tijuca, Mata do Rumo, 19.I.1969, fl. e fr., D. Sucre 4461 \& P. I. S. Braga 1338 (RB); Saquarema, Restinga de Ipitangas, 24.III.1987, st., C. Farney 1360 (RB).

Distribuição geográfica e habitat: exclusiva do estado do Rio de Janeiro, onde ocorre nas regiões Metropolitana, Serrana Central e Lagos (Fig. 3). Na região Serrana, ocorre no município de Guapimirim e Duque de Caxias, em Floresta Ombrófila Densa Submontana (60-400 m s.m.); na região Metropolitana é relativamente comum nos maciços litorâneos da Serra Carioca, também em Floresta Ombrófila Densa Submontana (80-100 m s.m.), em vegetação de formação secundária. Na Região dos Lagos, foi coletada apenas na restinga de Saquarema. Dados fenológicos: coletada com flores em dezembro e janeiro e com frutos em agosto, janeiro e fevereiro.

Stylogyne depauperata apresenta nervação foliar campto-broquidódroma, sépalas com ápice fortemente arredondado, pétalas simétricas com ápice arredondado e margem irregular, hialina. São arbustos de 


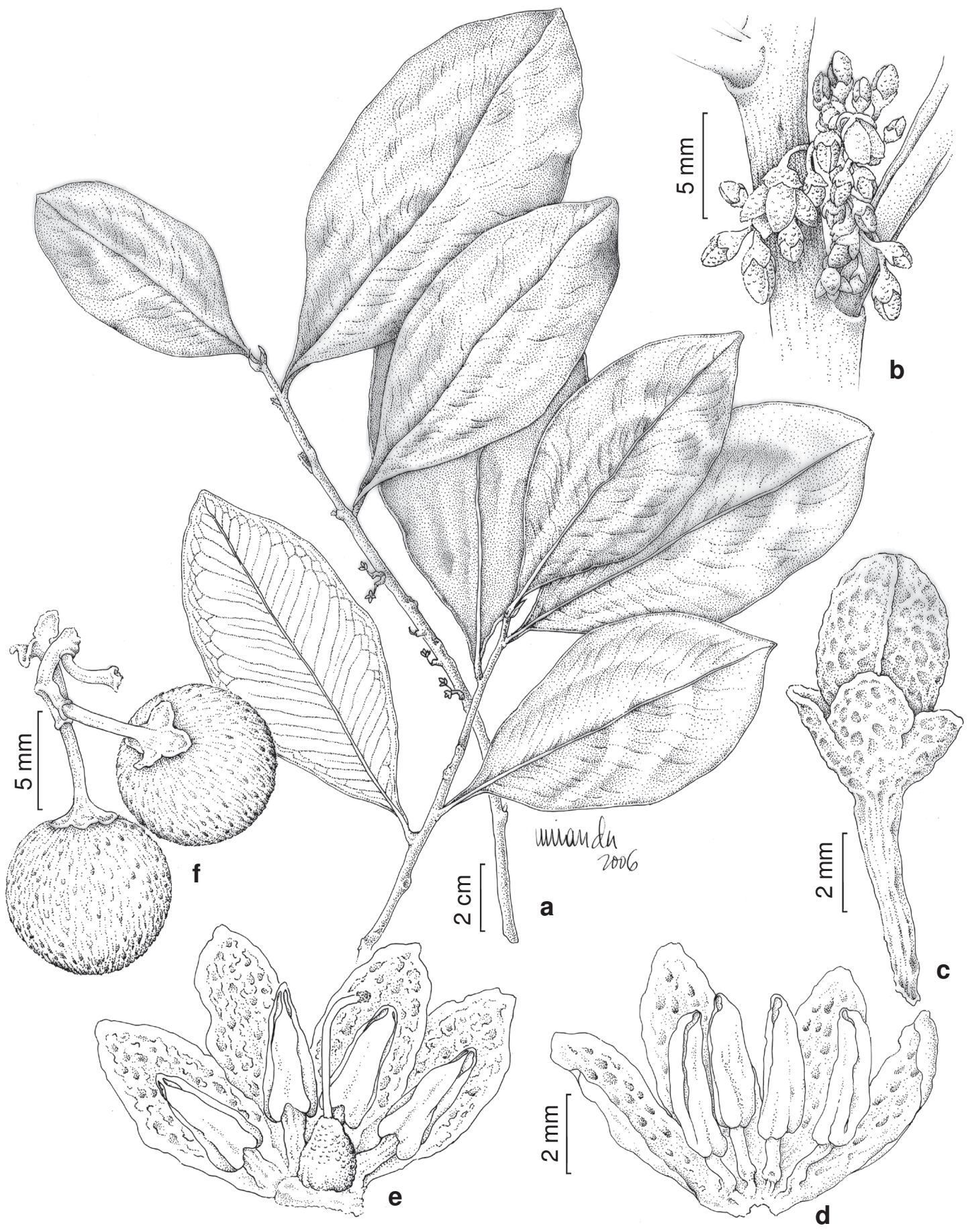

Figura 1 - Stylogyne depauperata - a. ramo com flores; b. inflorescência; c. flor em botão; d. flor estaminada; e. flor bissexual; f. frutos (a,d Rego 896; b,c, e Sucre 4461; f. Marquete 2990). 
caule único ou dicotômico pouco acima da base, com ramos candelabriformes e lenticelados; as folhas cartáceas apresentam densas pontuações translúcidas; as inflorescências pêndulas apresentam flores de coloração alva a creme e estames amarelos.

Esta espécie é muito freqüente na localidade conhecida como "Matas do Pai Ricardo", no Parque Nacional da Tijuca, onde populações de indivíduos em diferentes estágios de desenvolvimento apresentam padrão de distribuição agregado. Ilustração inédita.

3. Stylogyne laevigata (Mart. ex Miq.) Mez in Engl, Das Planzenreich 4(236): 266-267. t.30. 1902.

Arbustos ou árvores, 5-10 m alt. Ramos cilíndricos, 1,5-2,6 mm diam, glabros. Pecíolos profundamente canaliculados, 14-17,3(25) mm compr., 1,2-2,7(3,8) mm diâm.; lâmina foliar cartácea, obovada ou oblongo-obovada, 20,0$22,5(26,8) \times 7,5-9,5$, base atenuada, ápice arredondado ou agudo, nervação camptobroquidódroma nervuras secundárias tênues em ambas as faces, margem inteira, revoluta. Inflorescências terminais, paniculadas, 9-11,5 $\times 8-12 \mathrm{~cm}$, com ramificações corimbosas, bipenadas e tripenadas. Flores bissexuais e unissexuais (estaminadas), 5-meras, (3,5)4-5 mm compr., pedicelos cilíndricos, 1,5-3 mm compr., glabros; brácteas subcartáceas, lanceoladas, 1,5-2 mm compr., margem inteira, fimbriada no ápice; cálice 2,1-2,4 mm compr., com pontuações cilíndricas nigrescentes e alaranjadas, sépalas cartáceas, elípticas a oblongas, 1,3-1,8 × 0,8-0,9 mm, fusionadas 0,5-0,7 mm compr., eretas, ápice arredondado, margem uniforme, ligeiramente irregular; corola campanulada, pétalas subcartáceas, oblongo-elípticas, 4,2-4,5 mm compr., fusionadas 1,3-1,5 mm compr., com pontuações circulares e lineares nigrescentes, lobos 2,8-3 $\times 1,6-1,7 \mathrm{~mm}$, assimétricos, deflexos, ápice abruptamente acuminado, margem não hialina, levemente irregular; flores estaminadas com estames 4,9-5,3 mm compr., filetes filiformes, 4-4,3 mm compr., anteras oblongas, 1,2-1,5 $\times$ 1,5-2 mm, deiscentes por fendas laterais, base cordada, ápice obtuso; pistilódio subulado 1,21,6 mm compr. ou ausente; flores pistiladas com estaminódios 2-2,3 mm compr., filetes 1-1,5 $\mathrm{mm}$ compr., lineares, anteras elípticolanceoladas, 1,6-2 × 0,5-0,8 mm, deiscentes por fendas laterais, base cordada, ápice agudo; pistilo 3,5-4 mm compr., ovário elíptico-ovado, ca. 1,6 $\times 0,8 \mathrm{~mm}$, estilete 2,3-2,7 mm compr., cilíndrico, estigma capitulado. Fruto esferoidal, 6-6,5 × 7-7,5 mm, epicarpo com pontuações elípticas e circulares nigrescentes.

Material selecionado: BRASIL. RIO DE JANEIRO: Duque de Caxias, Reserva da Petrobrás, 27.VIII.1997, fl., J. A. L. Neto 671 (RB); Magé, Serra da Estrela, 16.XI.1977, fr., P. J. Maas 3248 (RB); Nova Friburgo, Galdinópolis, 2.X.2000, bt., A. Quinet 24/37 (RFA); Nova Iguaçu, estrada do Outro, 13.XI.2001, fr., S. J. Silva-Neto 1507 (RB); Paraty, estrada para Cunha, 16.III.1989, fr., A. L.Almeida 10 (RB); Rio de Janeiro, Bico do Papagaio, 16.III.1972, fr., J. Almeida 1377(RB); Silva Jardim, Reserva Biológica de Poço das Antas, st., 16.VIII.1995, J. M. A. Braga 2693 (RB).

Distribuição geográfica e habitat: restrita aos estados de Minas Gerais, São Paulo e Rio de Janeiro, onde ocorre na região Metropolitana, Serrana Central e Sul Fluminense (Fig. 3). Na região Metropolitana, é relativamente frequiente nos Maciços da Serra da Carioca, em Floresta Ombrófila Densa Submontana (60-100 m s.m.) de formação secundária; na região Serrana, ocorre em Floresta Ombrófila Densa Submontana a Montana na região de Serra dos Órgãos (100800 m s.m.), e nas Terras Baixas do Maciço do Tinguá. Na região Sul Fluminense, ocorre no Município de Paraty, em Floresta Ombrófila Densa Submontana (200-290 m s.m.).

Dados fenológicos: coletada com flores em agosto, setembro, outubro e novembro e com frutos em novembro e fevereiro.

Stylogyne laevigata apresenta maior afinidade com S. leptantha e S. lhoztkiana. De $S$. leptantha pode ser diferenciada pelas inflorescências expandidas (não compactadas), pétalas elíptico-ovadas de ápice agudo e acuminado (não oblongo-elípticas de ápice arredondado a truncado e emarginado), com pontuações glandulares circulares periféricas e elípticas centrais (não com pontuações lineares centrais). De S. lhotzkiana pode ser diferenciada 
pelas pétalas com pontuações glandulares circulares periféricas e elípticas centrais, nigrescentes (não lineares e brunas concentradas no centro) e estigma capitulado (não discóide).

Apesar da distribuição geográfica restrita ao Sudeste do Brasil, Stylogyne laevigata é relativamente freqüente no estado do Rio de Janeiro, e ocorre, inclusive, em áreas alteradas. Apresenta grande plasticidade fenotípica, sendo variáveis a forma e tamanho das folhas (não a arquitetura foliar), o comprimento e a largura das inflorescências e o tamanho das flores. Os estames das flores bissexuais são menores em comparação aos das flores estaminadas. Conhecida pelo nome comum "mangue-roxo". Ilustração em Miquel (1856), t.30.

4. Stylogyne leptantha (Miq.) Mez in Engl., Das Pflanzenreich 4(236): 273, t.32. 1902.

Fig. 2

Arbustos 4-5 m alt. Ramos cilíndricos, 3,23,9 mm diâm., glabros. Pecíolos subcilíndricos, 14-16,5 mm compr., 1,7-2,4 mm diâm.; lâmina foliar cartácea, elíptico-obovada ou oblanceolada, $16-17 \times 5,5-6 \mathrm{~cm}$, base e ápice agudos, margem inteira, nervação camptobroquidódroma tênue em ambas as faces, margem inteira, revoluta. Inflorescências terminais e subterminais, paniculadas, 5-6 $6 \times 2$ $2,5 \mathrm{~cm}$, bipenadas, compactadas. Flores unissexuais (pistiladas e estaminadas), 5-meras, $3-3,5 \mathrm{~mm}$ compr., pedicelos cilíndricos, 3,1-4 mm compr., com pontuações circulares nigrescentes; brácteas subcartáceas, lanceoladas, 1-2×0,5$1 \mathrm{~mm}$ compr.; cálice 1,2-1,6 mm compr., com pontuações circulares nigrescentes, sépalas subcartáceas, ovadas, $0,6-0,9 \times 0,6-0,7$, fusionadas 0,3-0,5 mm compr., eretas ou patentes, ápice agudo à levemente arredondado, margem uniforme, levemente irregular; corola campanulada, pétalas membranáceas, oblongas, 3-4 mm compr., fusionada 1,3-1,5 mm compr., com pontuações lineares brunas no centro, lobos 2,3-2,5 × 1,2-1,3 mm, ligeiramente assimétricos, deflexos, ápice fortemente arredondado a ligeiramente truncado, margem uniforme, inteira ou emarginada; flores estaminadas com estames 4-4,5 mm compr., filetes filiformes, 2,5-3 mm compr., anteras oblongas, 1,3-1,6 ×0,4-0,7 mm, versáteis, deiscente por fendas laterais, base sub-cordada, ápice obtuso; pistilódio 2,7-3 mm compr., densamente glanduloso, cônico na base e contínuo ao estilete cilíndrico, óvulos abortados, estigma capitulado; flores pistiladas com estaminódios 2,9-3,3 mm compr., filetes 2,32,6 mm compr., anteras elíptico-lanceoladas, $1,4-1,6 \times 0,4-0,7 \mathrm{~mm}$, deiscentes por fendas laterais, base cordada, ápice agudo, apiculado; pistilo 3,5-4 mm compr., ovário ovóide, ca. 1,2 $\times 0,5 \mathrm{~mm}$, glanduloso, 3-4 óvulos unisseriados, estilete 2-2,5 mm compr., estigma capitulado. Fruto esférico, 6-6,2×7-7,3 mm, pericarpo com pontuações elípticas e circulares nigrescentes. Material selecionado: RIO DE JANEIRO: Guapimirim, Paraíso, I.1975, fr., P. Occhioni 6704 (RFA); Serra dos Órgãos, 19.II.2002, fr., F. M. B. Pereira 17/74 (RFA); Paraíba do Sul, Limoeiro, 20.X.1974, fl., P. Occhioni 6352 (RFA); V.1974, fr., $P$. Occhioni 5950 (RFA); XI.1974, fl. e fr., P. Occhioni 6502 (RFA); Teresópolis, Dedo de Deus, 05.X.1974, fl., P. Occhioni 6294 (RFA); Serra dos Órgãos, 28.VII.2006, st., T. T. Carrijo 744 (RB).

Distribuição geográfica e habitat: restrita aos estados do Rio de Janeiro e Minas Gerais. No estado do Rio de Janeiro ocorre na região Serrana Central (Fig. 3), na divisa dos municípios de Guapimirim e Teresópolis, e no município de Paraíba do Sul. Habita Floresta Ombrófila Densa Montana (900 a 1.100 m s.m.).

Dados fenológicos: coletada com flores em outubro e novembro, e com frutos em janeiro, fevereiro, maio e novembro.

Stylogyne leptantha apresenta inflorescências paniculadas, compactadas, pétalas oblongo-elípticas de ápice arredondado a truncado e emarginado, com pontuações lineares centrais. São arbustos de interior de mata, com caules dicotômicos pouco acima da base e folhas adensadas no ápice dos ramos.

O dimorfismo sexual observado nesta espécie já foi registrado em Myrsinaceae (Heenan 2000), e pode ser interpretado como um caso de criptodioicia (Mayer \& Charlesworth 1991). As flores estaminadas apresentam estames ligeiramente maiores que o pistilódio, o qual é morfologicamente 


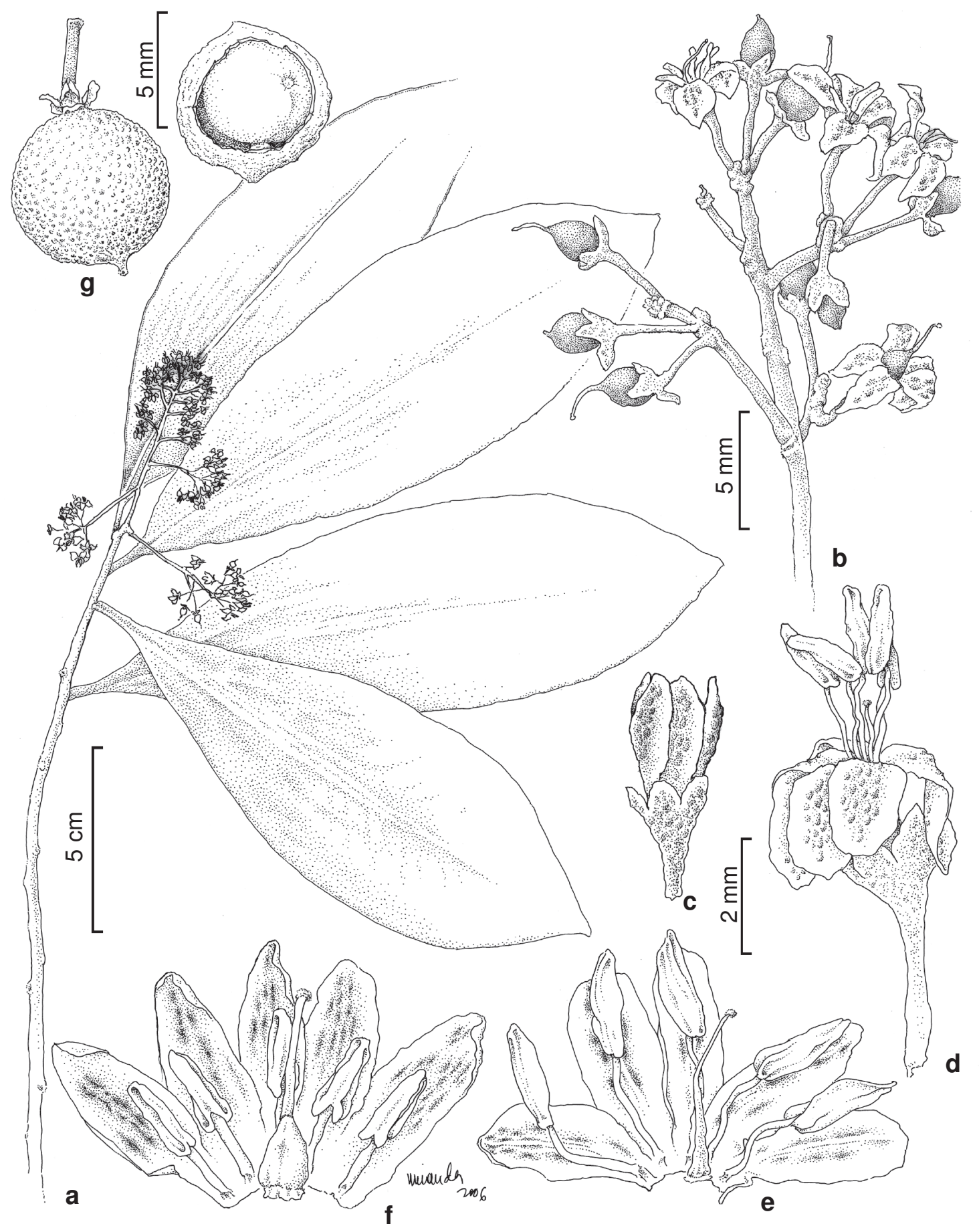

Figura 2 - Stylogyne leptantha - a. ramo com flores; b. inflorescência; c. botão floral; d. flor estaminada detalhando os lobos da corola deflexos; e. flor estaminada; f. flor pistilada; g. fruto e endosperma em detalhe. (a-d, f-g Occhioni 6502; e Occhioni 6352). 


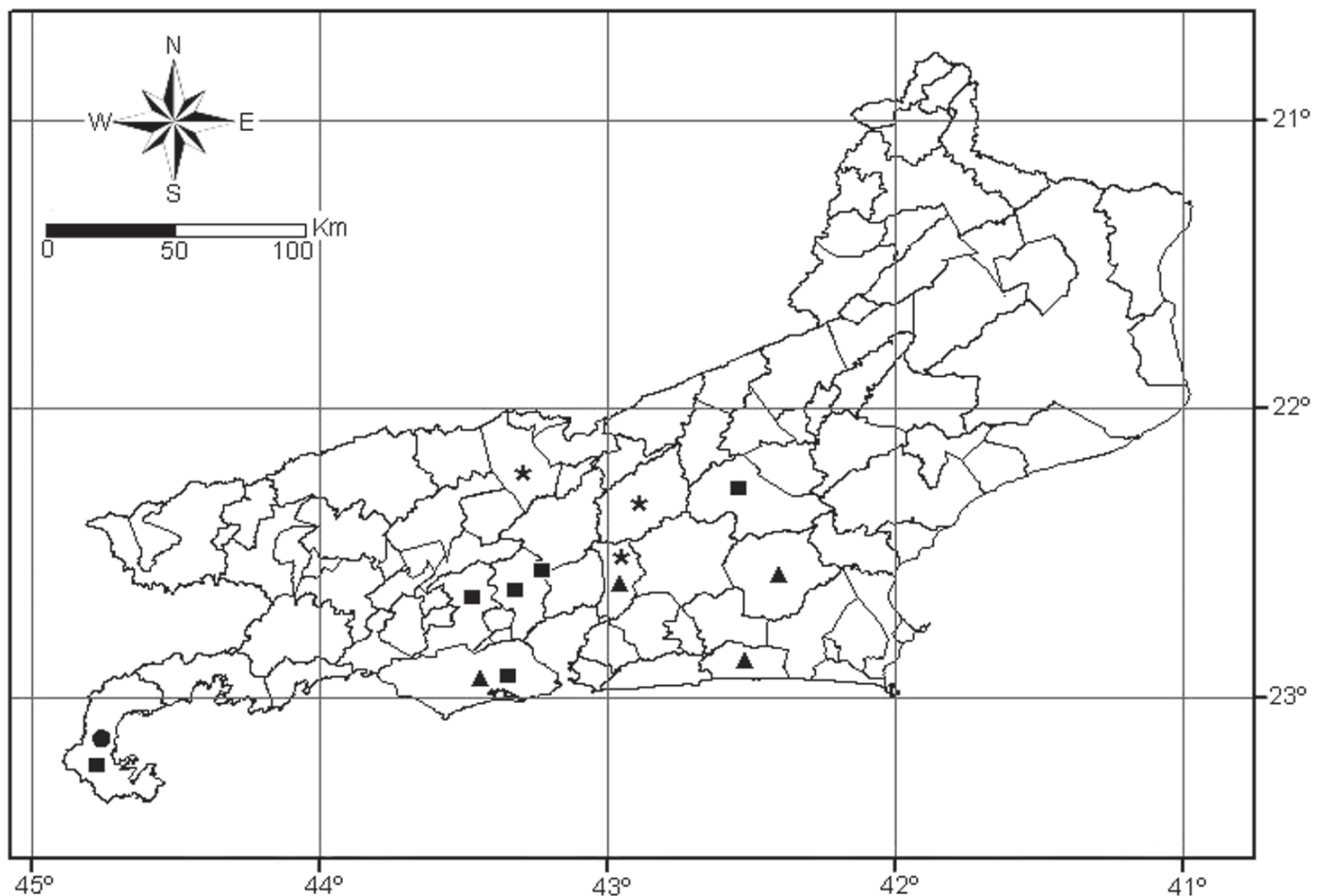

Figura 3 - Mapa de distribuição geográfica de Stylogyne sp. $\bullet$, S. depauperata $\boldsymbol{\Delta}$, S. laevigata $\bullet$ e S. leptantha * no estado do Rio de Janeiro.

desenvolvido (cônico na região do ovário, alongado e cilíndrico na região do estilete). As flores pistiladas apresentam estaminódios de menor comprimento em relação ao pistilo (pelo menor comprimento dos filetes) e anteras semelhantes às das flores estaminadas, porém estéreis. No estado do Rio de Janeiro é conhecida como "pau-cebola".

5. Stylogyne lhotzkyana (A.DC.) Mez in Engl., Das Pflanzenreich 4(236): 269. 1902.

Fig. 4

Arbustos 1,5-2 m alt. Ramos cilíndricos, 3,5-4 mm diâm., glabros. Pecíolos subcilíndricos, 16-8 mm compr., 1,5-2,2 mm diâm., glabros, com pontuações cilíndricas alaranjadas; lâmina foliar cartácea, elíptica, 15,5-18×6-7 cm, base e ápice agudos; nervação campto-broquidódroma, margem inteira, revoluta. Inflorescências terminais, paniculadas, 6,5-7 ×5,5-6 cm, com ramificações corimbosas, tripenadas. Flores estaminadas não vistas. Flores pistiladas 5-meras, 3,5-4 mm compr., pedicelos cilíndricos, 2
2,5 mm compr., glabros; brácteas lanceoladas, 1,4-1,9 mm, pontuações cilíndricas, alaranjadas, margem inteira, não hialina; cálice $1-1,5 \mathrm{~mm}$ compr., sépalas cartáceas, ovadas, 0,9-1 $\times$ $0,6-0,7 \mathrm{~mm}$, fusionadas ca. $0,6 \mathrm{~mm}$ compr., patentes ou eretas, com pontuações cilíndricas alaranjadas e lineares nigrescentes, margem ligeiramente irregular, não hialina; corola campanulada, pétalas cartáceas, elípticas, 3,94,1 mm compr., fusionada ca. $0,7 \mathrm{~mm}$, com conspícuas pontuações brunas e lineares centrais, lobos 3,2-3,5 × 1,8-2,0 mm, assimétricos, eretos, ápice agudo, por vezes emarginado, margem uniforme; estaminódios 2,9-3,2 mm compr., filetes ligulados, 1,8-2,1 mm compr., adnatos a base do tubo da corola, anteras elíptico-lanceoladas, 1,5-1,7 × 0,6$0,8 \mathrm{~mm}$, deiscentes por fendas laterais, base cordada, ápice agudo, apiculado; pistilo 3,3$3,5 \mathrm{~mm}$ compr., ovário ampuliforme, ca. 1,3× $0,8 \mathrm{~mm}$, com pontuações lineares nigrescentes, 3-4 ovulado, estilete cilíndrico, 1,9-2,2 mm compr., estigma discóide. Frutos não vistos. 


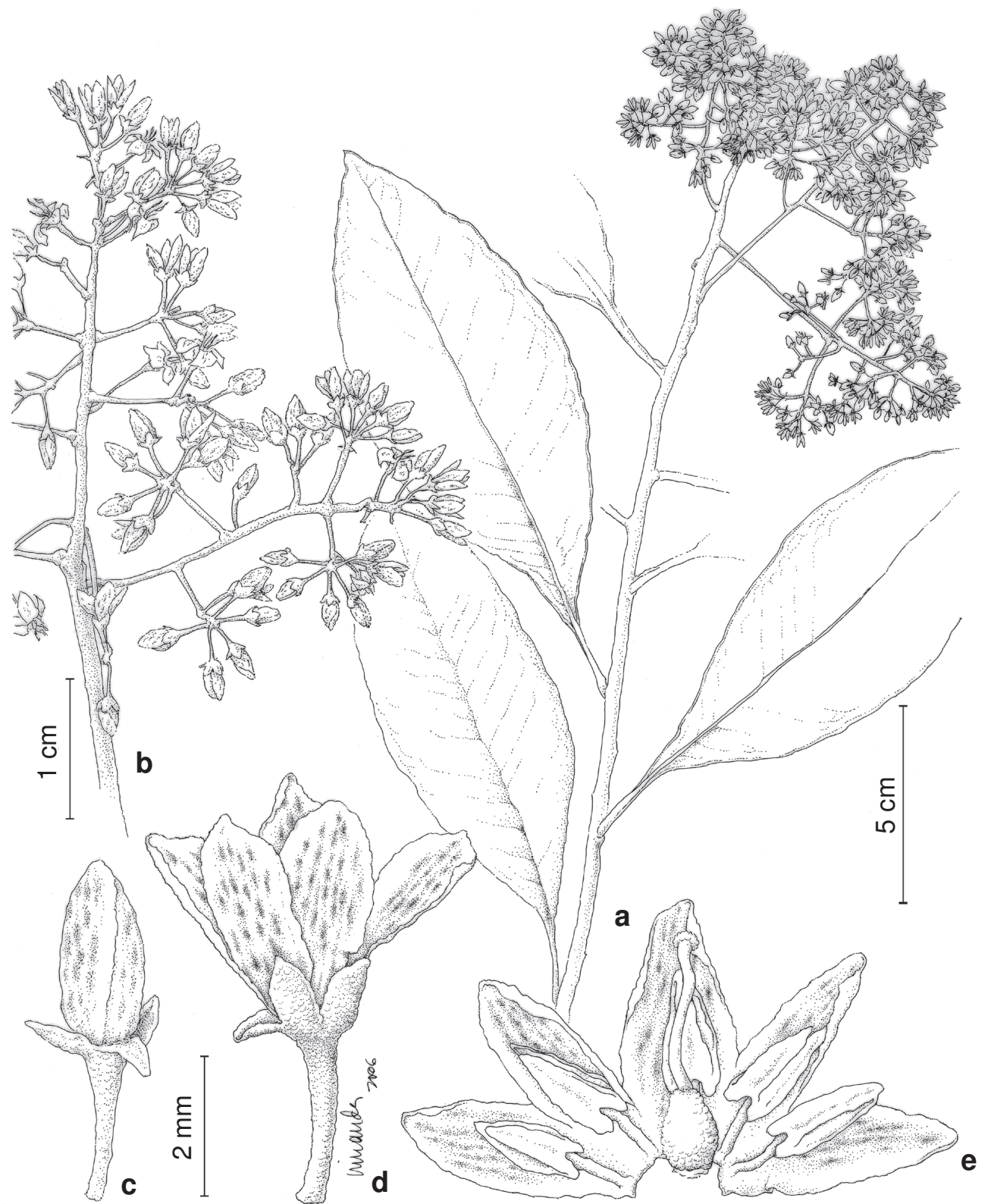

Figura 4 - Stylogyne lhotzkiana - a. ramo com flores; b. inflorescência; c. botão floral; d. flor pistilada detalhando os lobos da corola eretos; e. flor pistilada. (Pereira 24/039).

Material analisado: BRASIL. RIO DE JANEIRO: localidade desconhecida, 1832, fl., Lhotsky s.n. (F neg. 7479); Cachoeiras de Macacu, Fazendas Consorciadas Sertão, 8.X.2000, fl., F. M. B. Pereira 24/039 (RFA); Estação Ecológica do Alto Paraíso, s.d., st., B. C. Kurtz s.n. (RB 328406).

Distribuição geográfica e habitat: restrita ao estado do Rio de Janeiro. Ocorre no bloco da região Serrana Central (Fig. 8), na região limítrofe entre os municípios de Cachoeiras de Macacu e Guapimirim, incluído a área abrangida pela
Estação Ecológica do Paraíso. Habita Floresta Ombrófila Densa Submontana (ca. 200 m s.m.). Dados fenológicos: coletada com flores em outubro.

Stylogyne lhotzkiana é distinta das demais espécies do estado do Rio de Janeiro pelas inflorescências piramidais, flores com pontuações lineares e brunas concentradas no centro das pétalas e estigma discóide.

A espécie foi descrita com base no holótipo (Lhotzky 1832), de flores estaminadas. As 
descrições posteriores realizadas para a espécie (De Candolle 1844; Miquel 1856; Mez 1902) foram embasadas neste mesmo exemplar, de forma que a descrição das flores pistiladas é apresentada pela primeira vez. Ilustração inédita.

Kurtz \& Araújo (2000) analisaram um trecho de mata da Estação Ecológica do Alto Paraíso, um dos locais de coleta de S. lhoztkiana na região de Guapimirim. Os autores caracterizaram a área como clímax ou em estágio sucessional muito próximo. Os autores informaram, ainda, que esta unidade de conservação está sob influência direta das chuvas de relevo provocadas pela presença do paredão abrupto e dos altos cumes da Serra dos Órgãos, que interceptam os ventos úmidos vindos do litoral, gerando uma elevada umidade relativa do ar. A conjunção destes fatores torna a área especialmente propícia aos representantes de Stylogyne. A existência de uma Unidade de Conservação na área contribui para a conservação de $S$. lhotzkiana, mas as áreas de planície fora dos limites da Estação Ecológica do Alto Paraíso foram quase totalmente desmatadas em função da atividade pecuária e da agricultura de subsistência. Atualmente, a maior parte da vegetação remanescente da região está concentrada nas colinas.

\section{Stylogyne pauciflora Mez, Das} Planzenreich 4(236): 278. $1902 . \quad$ Fig. 5

Arbustos ou arvoretas 1-2 m. Ramos cilíndricos, 1,6×1,9 mm diâm., glabros, raro glabrescentes. Pecíolos canaliculados, 7,4-13,2 mm compr., 1,2-1,4 mm diâm., lâmina foliar cartácea, elíptica à ligeiramente elíptico-ovada, $(9,6) 11,1-$ $12(15,5) \times(3,3) 3,7-5,5 \mathrm{~cm}$, base atenuada, ápice acuminado, nervação campto-broquidódroma, margem inteira ou levemente irregular. Inflorescências terminais (raro ramifloras) corimbosas, 3,4-4 cm compr., bipenadas. Flores bissexuais e unissexuais (estaminadas), 4-meras, 4-5 mm compr., pedicelos cilíndricos, 4-10,5 mm compr., glabros; brácteas cartáceas, 2-2,2 mm compr., lanceoladas, glabras, margem levemente irregular; cálice 1,5-1,8 mm compr., com pontuações inconspícuas, sépalas cartáceas, ovadas, $1,0-1,2 \times 0,7-0,9 \mathrm{~mm}$, fusionada na base, eretas, ápice agudo, margem hialina, ligeiramente irregular; corola campanulada, pétalas membranáceas, largamente elípticas, 4-4,4 mm compr., fusionadas ca. $0,5 \mathrm{~mm}$ compr., com pontuações alaranjadas lineares centrais e cilíndricas periféricas, lobos elípticos, 3,5-3,9 × 1,3-1,5 mm, assimétricos, deflexos a revolutos, ápice agudo, por vezes emarginado, margem inteira, não hialina; flores estaminadas com estames 3,1-3,6 mm compr., filetes ligulados, 1-1,3 mm compr., adnatos a base do tubo da corola, anteras oblongo-elípticas, 1,9$2,2 \times 0,6-0,9 \mathrm{~mm}$, deiscentes por fendas laterais com ápice dilatado, base cordada, ápice agudo, apiculado, coberto por pequenas pontuações alaranjadas; pistilódio cônico, 1,5$1,7 \mathrm{~mm}$ compr. ou ausente; flores bissexuais com estames 2,5-3 $\mathrm{mm}$ compr., filetes ligulados, $0,7-1,2 \mathrm{~mm}$ compr., adnatos a base do tubo da corola, anteras oblongo-elípticas, $1,8-2 \times 0,5-0,8 \mathrm{~mm}$, deiscentes por fendas laterais com ápice dilatado, base cordada, ápice agudo, apiculado; pistilo 2,5-3 mm compr., ovário ovóide, 1,2-1,6×1,7-1,9 mm, coberto por diminutas pontuações alaranjadas na base, 4-5 óvulos unisseriados, estilete cilíndrico, 1,31,6 mm compr., estigma puntiforme ou ligeiramente 3-lobado. Fruto esférico, 7,4-8× $7,5-8,2 \mathrm{~mm}$, pericarpo rugoso com densas pontuações lineares e nigrescentes.

Material selecionado: BRASIL. RIO DE JANEIRO: Nova Iguaçu, Estrada para Itacolomi, 11.XII.2001, fr., J. A. Silva-Neto 1556 (RB); Teresópolis, PARNA de Serra dos Órgãos, 25.XII.1942, fl., S. W. Barros 1161 (RB); PARNA de Serra dos Órgãos, 25.XI.1942, fl., E. Pereira 181 (RB); PARNA de Serra dos Órgãos, 4.X.1980, fl., H. C. Lima 1547 (RB); PARNA de Serra dos Órgãos, 17.VIII.1983, fl., G. Martinelli 9311 (RB); PARNA de Serra dos Órgãos, 23.XI.2005, fl., T. T. Carrijo 289 (RB); PARNA de Serra dos Órgãos, 21.I.2006, fr., T. T. Carrijo 450 (RB, SP); PARNA de Serra dos Órgãos, 21.I.2006, st., T. T. Carrijo 451 (RB, SP); PARNA de Serra dos Órgãos, 21.I.2006, fr., T. T. Carrijo 452 (RB, SP); PARNA de Serra dos Órgãos, 21.I.2006, fr., T. T. Carrijo 453 (RB, SP); PARNA de Serra dos Órgãos, 15.I.2005, st., C. C. S. Seele 588 (RB); PARNA de Serra dos Órgãos, 15.I.2006, fr., $C$. C. S. Seele 577 (RB); PARNA de Serra dos Órgãos, 15.I.2206, fr., C. C. S. Seele 576 (RB). 


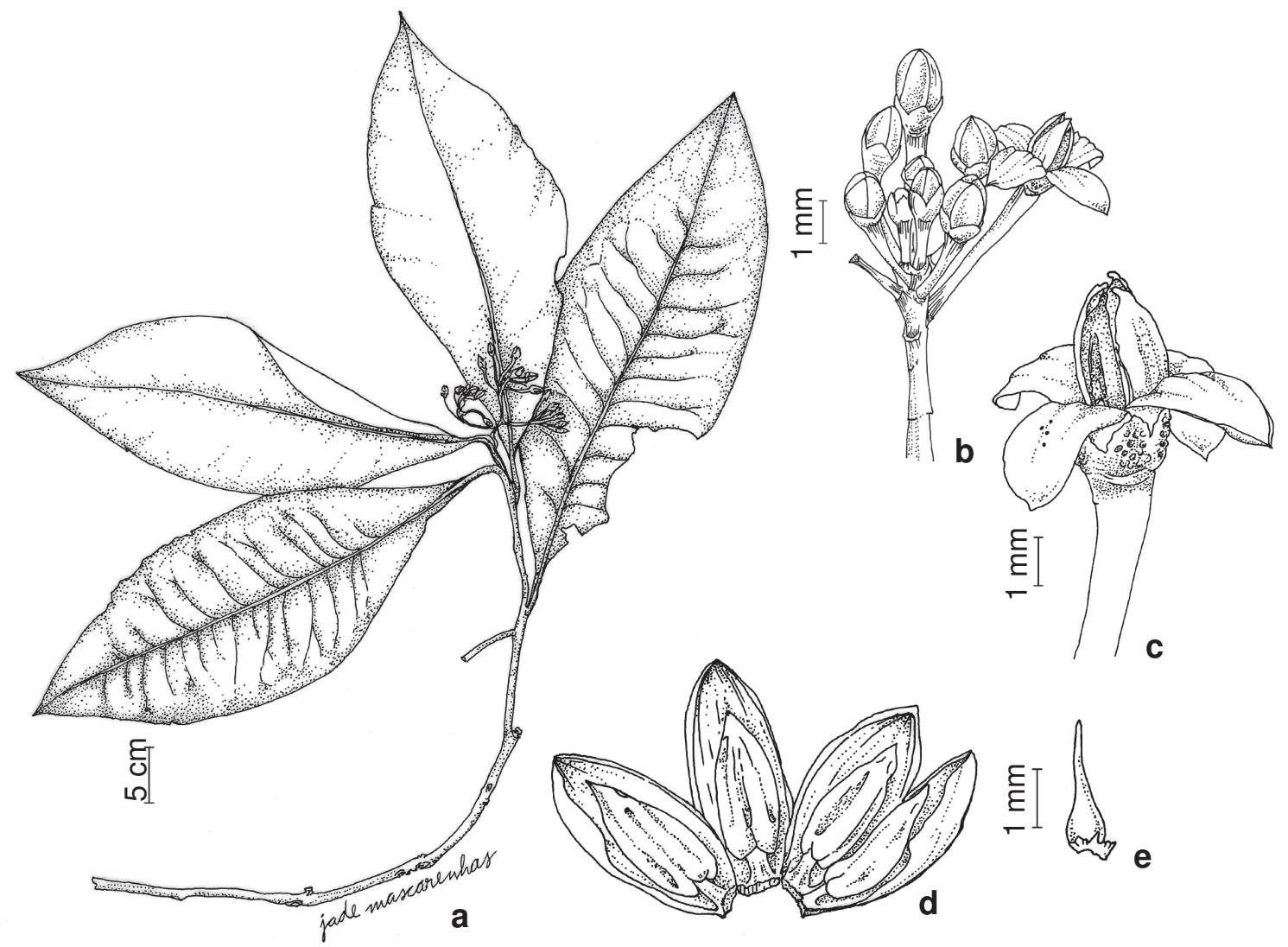

Figura 5 - Stylogyne pauciflora - a. ramo com flores; b. inflorescência; c. flor em antese; d. flor estaminada; e. pistilódio (Carrijo 289).

Material adicional analisado: BRASIL. SÃO PAULO, localidade desconhecida, s.d., fl., F. Sellow 472 (F neg. 4843).

Distribuição geográfica e habitat: restrita aos estados do Rio de Janeiro e São Paulo, onde ocorre na região Serrana Central (Fig. 8), nos Municípios de Teresópolis e Nova Iguaçu, em Floresta OmbrófilaDensa Montana (900 a 1.250 m s.m.). Dados fenológicos: coletada com flores em agosto, outubro e novembro, e com frutos em janeiro.

Stylogyne pauciflora mostra maior afinidade com $S$. sellowiana e $S$. sordida. De $S$. sellowiana é diferenciada pelo caule cespitoso (não único), córtex avermelhado (não esverdeado), folhas de margem inteira (não serrilhada) e inflorescências terminais e ramifloras (não axilares e ramifloras). De $S$. sordida é diferenciada pelas inflorescências corimbosas (não fasciculadas) e pétalas assimétricas (não simétricas), pontuadas.

São arbustos cespitosos de caules eretos, subprostrados ou rastejantes, com secreção interna avermelhada quando a cascaé removida. Os caules rastejantes, aéreos ou subterrâneos, alcançam distâncias de até $2 \mathrm{~m}$ da planta mãe, emitindo novas ramificações semelhantes a plântulas. Essa disposição espacial, se não observada atentamente, pode ser equivocadamente interpretada como um padrão de distribuição agregada dos indivíduos (semelhante à observada em populações de $S$. depauperata). Raramente os caules rastejantes originam raízes adventícias, o que os descaracteriza como estolões típicos. As inflorescências são pêndulas e as flores alvas apresentam pontuações lineares de coloração vinácea, que assumem uma coloração alaranjada no material herborizado. Os frutos são nigrescentes e lustrosos quando maduros. Ilustração inédita.

7. Stylogyne sellowiana Mez in Engl., Nat. Pflanzenreich 4(236): 278. 1902 . Fig. 6

Arbustos 1,5-2 m alt. Ramos cilíndricos, 1,5-2,2 mm diâm., glabros, lenticelados. 


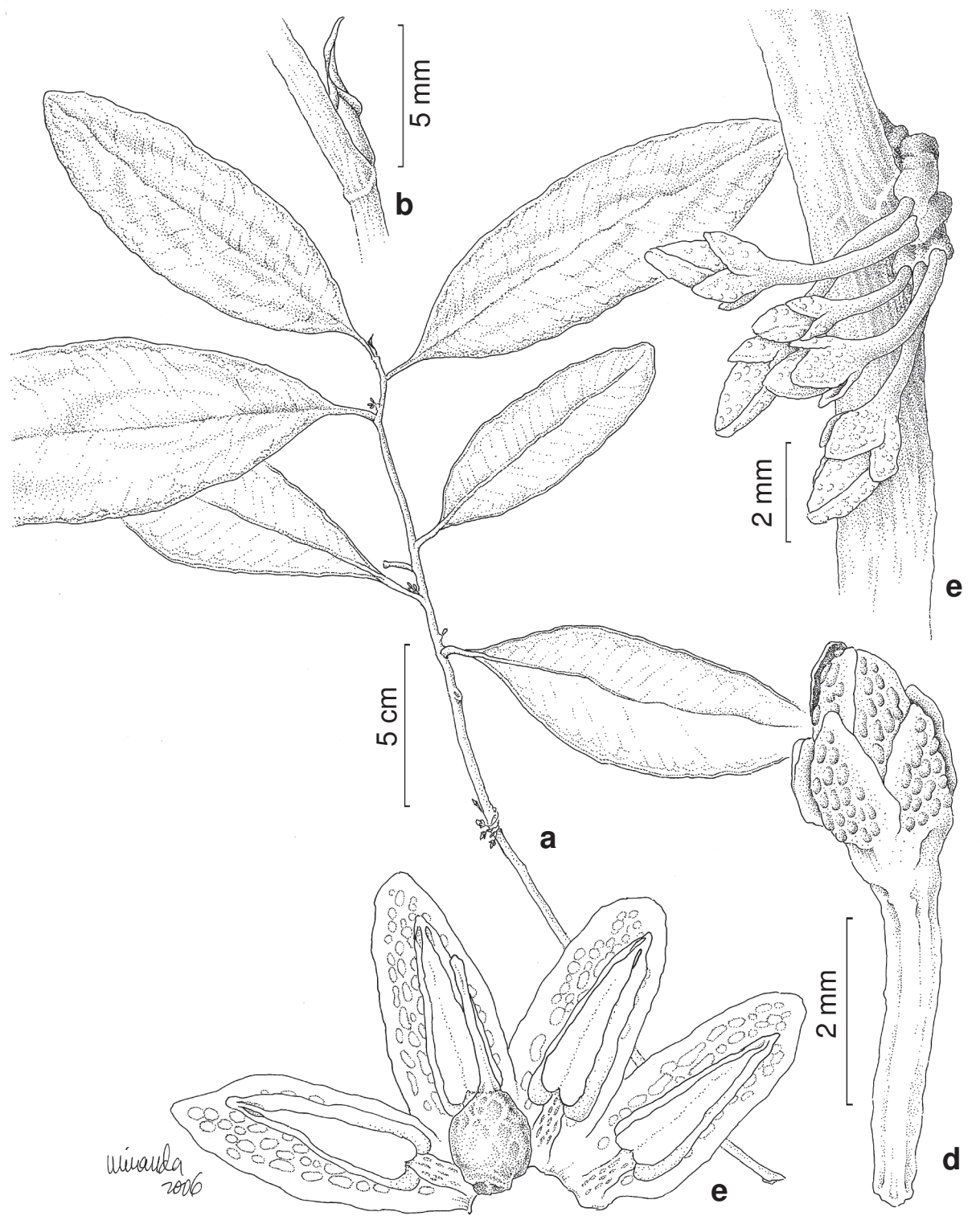

Figura 6 - Stylogyne sellowiana - a. ramo com flores; b. gema terminal; c. inflorescência; d. botão floral; e. flor bissexual. (Carrijo 136)

Pecíolos canaliculados, 9-12 mm compr., 1,11,3 mm diâm., glabros; lâmina foliar cartácea, elíptico-oblonga a elíptico-obovada, 14,5-15,7 $\times 4,5-5 \mathrm{~cm}$, base aguda à arredondada, ápice agudo, nervação campto-broquidódroma, margem serrilhada. Inflorescências axilares, corimbosas, 2-2,5 cm compr., bipenadas ou tripenadas. Flores estaminadas não vistas. Flores bissexuais 4-meras, 3-4 mm compr., pedicelos 3,7-4,9 mm compr., com pontuações alaranjadas, glabros; bractéolas caducas; cálice 1,5-1,7 mm compr., com pontuações alaranjadas, cilíndricas e conspícuas, sépalas coriáceas, ovadas, 1-1,4 $\times 1-1,2 \mathrm{~mm}$., eretas, margem irregular, hialina; corola campanulada, pétalas $3,2-3,5 \mathrm{~mm}$ compr., fusionada ca. $0,7 \mathrm{~mm}$ compr., lobos elípticos, 2,5-2,8 × 1,8-2,1 mm, assimétricos, deflexos, com pontuações elípticas e cilíndricas alaranjadas e proeminentes, ápice agudo, margem ligeiramente irregular, hialina; estames $1,8-2,2 \mathrm{~mm}$ compr., filetes ligulados, $0,5-0,7 \mathrm{~mm}$ compr., adnatos à base do tubo da corola, base alargada, com diminutas pontuações cilíndricas alaranjadas, anteras lanceoladas, 2,1-2,5 ×0,5- 
0,8 mm, base cordada, ápice agudo, apiculado, deiscentes por fendas laterais com ápice dilatado; pistilo 2,5-2,8 mm compr., ovário ca. $1,1 \times 0,7 \mathrm{~mm}$, coberto por pontuações, 5 óvulos unisseriados, estilete cilíndrico, 1,0-1,4 mm compr., estigma truncado. Frutos não vistos.

Material selecionado: RIODEJANEIRO: Rio de Janeiro, Parque Estadual da Pedra Branca, Grumari, 7.XI.2004, bot. efl., T. T. Carrijo 136(RB); 19.III.2006, st., T. T. Carrijo 480 (RB); 24.XI.2007, fl. e fr., T. T. Carrijo 1225 (RB); localidade desconhecida, fl., F. Sellow s.n. (Fneg. 4844).

Distribuição geográfica e habitat: restrita ao estado do Rio de Janeiro, onde foi coletada exclusivamente na região Metropolitana, na extremidade sul do Parque Estadual da Pedra Branca (Fig. 8). Habita Floresta Ombrófila Densa Submontana (ca. 250 m s.m.).

Dados fenológicos: coletada com flores e frutos jovens em novembro.

Stylogyne sellowiana pode ser reconhecida pelas folhas com margem serrilhada, com pontuações translúcidas abundantes, inflorescências estritamente axilares, pétalas assimétricas com margem hialina e irregular, e anteras sagitadas.

São arbustos de interior de mata, com caules lisos, dicotômicos pouco acima da base e apresentam a casca interna esverdeada. As flores apresentam pedicelos distintamente vináceos e corola alva; os lobos são deflexos a revolutos e apresentam densas pontuações lineares de coloração amarela; as anteras são distintamente lanceoladas e, quando maduras, apresentam o ápice dilatado e liberam grande quantidade de grãos de pólen, que ficam dispostos sobre as pétalas.

Os indivíduos não apresentam padrão de distribuição agregado como observado em outras espécies, mas também ocorrem em encosta voltada à vertente sul, de maior umidade. Essas coletas representam os primeiros registros da espécie em coleções do Brasil. O tipo que embasou a única descrição existente para a espécie (Mez 1902), apresenta flores estaminadas. Desta forma, as flores bissexuais são descritas pela primeira vez. Ilustração inédita.
8. Stylogyne sordida Mez in Engl., Das Pflanzenreich 4(236): 277. $1902 . \quad$ Fig. 7

Arbusto ca.1,5 m alt. Ramos cilíndricos, 2-3 mm diâm., glabros, coberto pontuações inconspícuas alaranjadas. Pecíolos subcanaliculados, 10-16 mm compr., 1,9-2,1 mm diâm., atenuados, glabros; lâmina foliar cartácea, elíptica a elíptico-lanceolada, 13-14,2 ×5-5,5 $\mathrm{cm}$, base aguda, ápice agudo a ligeiramente acuminado, nervação campto-broquidódroma, margem levemente serrilhada. Inflorescências axilares e ramifloras, 1-1,5 cm compr., fasciculadas. Flores bissexuais ou pistiladas (não vistas) e estaminadas, 4-meras, 3,0-3,5 mm compr., pedicelos cilíndricos, 3,5-4 mm compr., glabros, brácteas caducas, não vistas; cálice 1,5-1,7 mm compr., sépalas cartáceas, arredondadas, 0,8-1 × 0,5-0,6 mm, eretas, ápice largamente arredondado, fusionadas na base, margem uniforme, levemente crenulada; corola campanulada, pétalas 2,8-3,3 mm compr., fusionada ca. $0,5 \mathrm{~mm}$ compr., com indumento glandular na região basal da face adaxial do tubo, lobos elípticos, 2-2,2 × 1,21,4 mm, deflexos, ápice agudo, margem inteira, não hialina; estames 2,1-2,4 mm compr., filetes ligulados, 0,9-1,1 mm compr., adnatos à base do tubo da corola, anteras elíptico-lanceoladas, $1,2-1,6 \times 0,6-0,9 \mathrm{~mm}$, deiscentes por fendas laterais com ápice dilatado, base cordada, ápice obtuso, apiculado, pistilódio ausente. Frutos não vistos.

Material selecionado: BRASIL. RIO DE JANEIRO: Teresópolis, Serra dos Órgãos, 9.XI.1973, fl., D. Araújo 534 \& A.L.Peixoto 280 (RB); localidade desconhecida, s.d., fl., F. Sellow s.n. (F. Neg. 4846). Distribuição geográfica e habitat: exclusiva do estado do Rio de Janeiro. Ocorre na região Serrana Central, no município de Teresópolis (Fig. 8), em Floresta Ombrófila Densa Submontana (ca. 400 m s.m.).

Dados fenológicos: coletada com flores em novembro.

Stylogyne sordida pode ser diferenciada das demais espécies de Stylogyne do estado do Rio de Janeiro pelas inflorescências fasciculadas e flores com pétalas simétricas não pontuadas. 


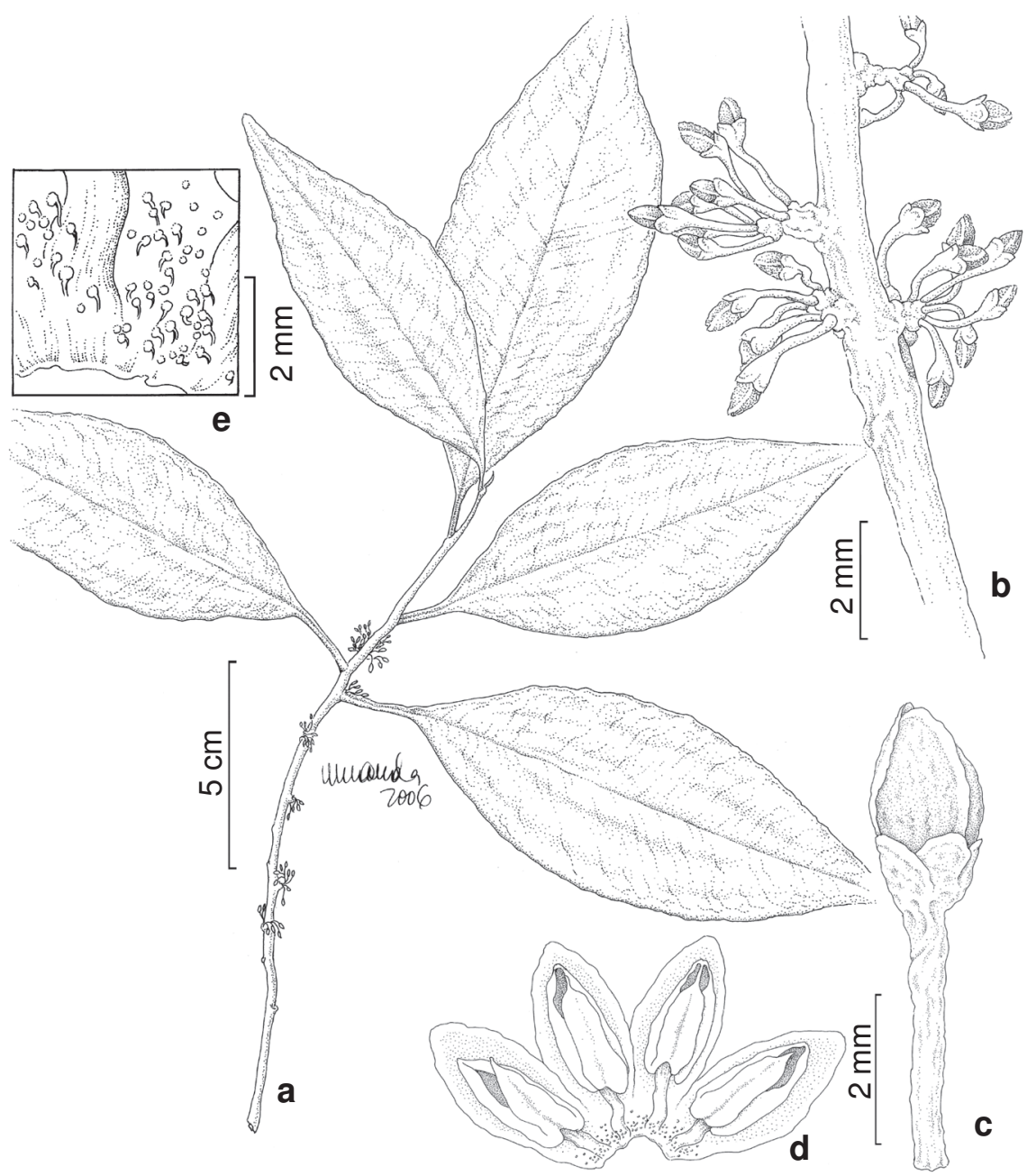

Figura 7 - Stylogyne sordida - a. ramo com flores; b. inflorescência; c. botão floral; d. flor estaminada; e. detalhe da face interna da base do tubo da corola (Araújo 534).

O espécime depositado no herbário RB representa o único registro da espécie em coleção no Brasil, e apresenta flores estaminadas, assim como os exemplares descritos na obra original (Mez 1902). Ilustração inédita.

\section{Conclusão}

Das oito espécies de Stylogyne ocorrentes no estado do Rio de Janeiro, quatro são exclusivamente fluminenses ( $S$. depauperata, S. lhotskiana, S. sellowiana e S. sordida). A região Serrana Central apresentou a maior diversidade de espécies (7 spp.), seguido das regiões Metropolitana (5 spp.), Sul Fluminense ( 2 spp.) e Região dos Lagos, com uma espécie. A Serra do Mar se destaca como importante centro de diversidade para Stylogyne no estado do Rio de Janeiro, especialmente os contrafortes da Serra dos Órgãos e do Maciço do Tinguá. Nenhum táxon foi registrado para o Norte Fluminense e Serra da Mantiqueira, embora as características fisionômicas destas regiões pareçam propícias às espécies do gênero.

Os representantes de Stylogyne predominam no estrato arbustivo, geralmente em ambientes sombreados, e quando não próximos a cursos de água, ocupam áreas úmidas ou nebulosas. As espécies predominam em Floresta Ombrófila Densa Submontana, em elevações de 60-400 m s.m., preferencialmente na faixa altimétrica de 200-290 m s.m. Apenas Stylogyne leptantha e $S$. pauciflora foram encontradas exclusivamente 


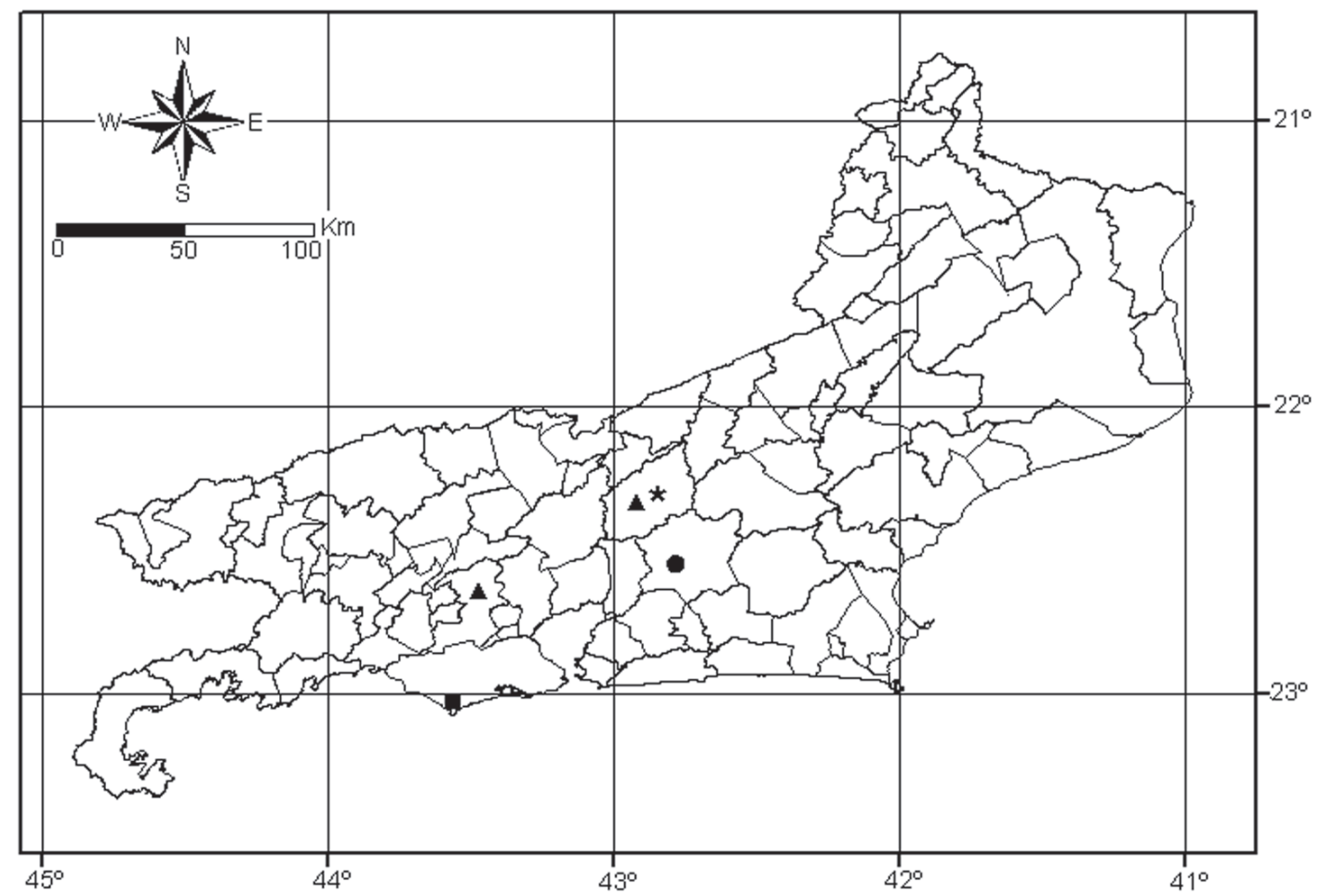

Figura 8 - Mapa de distribuição geográfica de Stylogyne lhotzkiana $\bullet$, S. pauciflora $\boldsymbol{\bullet}$, S. sellowiana $\bullet$ e $S$. sordida $\star$ no estado do Rio de Janeiro.

em Floresta Ombrófila Densa Montana, alcançando 900-1.250 m s.m. Stylogyne depauperata apresentou a maior variação altitudinal dentre as espécies do estado do Rio de Janeiro (10-400 m s.m.), sendo também a única a ocorrer em Restinga. Nenhuma espécie foi encontrada em campos de altitude. O habitat e altitude registrados para os representantes de Stylogyne no estado do Rio de Janeiro são semelhantes aos sinalizados para os táxons da América Central (Ricketson \& Pipoly 1997, 2003) e na América do Sul (Pipoly 1991, 1999; Pipoly \& Ricketson 1999, 2000), e reforçam a ocorrência preferencial dos representantes do gênero em Florestas Pluviais.

Com base neste levantamento, e em inventários e listas de espécies realizadas para Myrsinaceae nos estados de São Paulo (Bernacci \& Jung-Mendaçolli 2000; JungMendaçolli et al. 2005) e Minas Gerais (Oliveira-Filho 2006), Stylogyne está representado por 10 espécies na região sudeste do Brasil, sendo oito registradas para o estado do Rio de Janeiro, quatro para o estado de São Paulo e três para o estado de Minas Gerais. Apenas S. ambigua (Mart.) Mez e S.warmingii Mez, que ocorrem nos estados de Minas Gerais e São Paulo, não foram encontradas no estado do Rio de Janeiro. Nenhuma espécie do gênero foi registrada, até o momento, para o Espírito Santo, mas novas ocorrências podem ser esperadas para este estado.

Por suas flores bissexuais e unissexuais, estivação contorta do cálice e da corola, estames livres entre si e ovário pauciovulado, com óvulos unisseriados, as espécies do estado do Rio de Janeiro se enquadram na circunscrição de Stylogyne, apesar do posicionamento de Bernacci \& Jung-Mendaçolli (2000) e JungMendaçolli et al. (2005). Dois grupos de táxons foram reconhecidos com base na morfologia: o primeiro de inflorescências paniculadas, flores pentâmeras e anteras rimosas; o segundo de inflorescências corimbosas a fasciculadas, 
flores tetrâmeras e anteras deiscentes por rimas curtas de ápice alargado. Estas características talvez possibilitem um futuro arranjo taxonômico infragenérico para as espécies.

\section{LISTA DE EXSICATAS}

Almeida,A.L. 10 (3); Almeida, J. 1377 (3); Araújo 534 (8), 9320 (2); Barros 1161 (6); Botelho 49 (2); Braga 2693 (3) Carrijo 744 (4); 450, 451, 452, 453, 454 (6), 136 (7), 480 (7), 1006 (2), 1225 (7); Castelar 19 (1), 10 (3); Coelho 658 (1), 652 (3); Cordeiro 2360 (1); Duarte 294 (3); Duarte 96 (3); Giordano 1279 (2), 2026 (3); Glaziou 4073 (2), 15185 (3); Kuhlmann RB152817 (3); Lima 1547 (6); Lira-Neto 671 (2); Lhotsky F7479 (5); Marquete 672 (2), 2982 (2), 2990 (2); Martinelli 10431 (3), 9311 (6); Maas 3248 (3); Neto. 671 (3); Occhioni 6871 (2); 705 (3); 248 (2), 249(3), 6704 (4), 6352 (4), 5950 (4), 6502 (4); 6294 (4); Oliveira 1.048 (3); Pereira, E. 181 (6); Pereira, F.M.B. 17/74 (4), 24/039 (5); Pessoal do Horto Florestal RB 152815 (2), RB152817 (3); Quinet 24/ 37 (3); Seele 576 (6), 577 (6), 588 (6); Sellow 472 (6), F neg. 4844 (7), F neg. 4846 (8); Silva Neto 1507 (3); 1556 (6); Sucre 4461 (2), 4697 (2), 3571 (3); Rego 896 (2); Sá 1360 (2).

\section{Agradecimentos}

Aos curadores dos herbários citados pela facilitação de consulta ao acervo. À CAPES, pela concessão da bolsa de estudos da primeira autora, e ao Instituto de Pesquisas Jardim Botânico do Rio de Janeiro pelo suporte logístico. A Ricardo Woods de Lacerda e Marcelo D. M. Vianna Filho pelas sugestões e correções de uma versão preliminar do manuscrito, e aos revisores ad hoc pela revisão e sugestões do texto final. A Cláudia de Miranda e Jade Mascarenhas pela confecção das ilustrações.

\section{REFERÊNCIAS BIBLIOGRÁFICAS}

Bernacci, L. C. \& Jung-Mendaçolli, S. 2000. Considerações taxonômicas e novas combinações em Ardisia Sw. (Myrsinaceae) do Sudeste do Brasil. Acta Botanica Brasilica 14(3): 243-249.

De Candolle, A. 1837. A review of the Natural Order Myrsineae. Transact. Linn. Soc. Lond. 12: 95-138.
1841. Second mémoire sur la famille des Myrsinéacées, Ann. Sci. Nat., Bot., ser. 2, 16: 65-97.

1844. Myrsinaceae. In: Candolle, A. Prodr. Syst. 8: 75-140.

Heenan, P. B. 2000. Dioecism in Elingamita johnsonii (Myrsinaceae). New Zealand Journal of Botany 38: 569-574.

Holmgren, P. K. \& Holmgren, N. H. Index Herbariorum on the Internet. Disponível em <http://www.nybg.org/bsci/ih.ih.html>. (Acesso em: 01/08/2006).

IBGE. 1992. Manual técnico da vegetação brasileira. Manuais técnicos em geociências. N. 1. Departamento de Recursos Naturais e Estudos Ambientais, Rio de Janeiro 92p.

Jung-Mendaçoli, S. L. \& Bernacci, L. C. 1997. Flora fanerogâmica da ilha do Cardoso (SP, Brasil): Myrsinaceae. In: Melo, M. M. R. F.; Barros, F.; Chiea, S. A. C.; Kirizawa, M.; Jung-Mendaçoli, S. L. \& Wanderley, M. G. L. (eds.). Flora fanerogâmica da ilha do Cardoso. São Paulo 5: 81-98.

Jung-Mendaçoli, S. L. \& Bernacci, L. C. 2001. Myrsinaceae da APA do Cairuçu, Parati (Rio de Janeiro, Brasil). Rodriguésia 52 (81): 49-64.

Jung-Mendaçoli, S. L.; Bernacci, L. C. \& Freitas, M. F. 2005. Myrsinaceae. In: Wanderley, M. G. L.; Shepherd, G. J.; Melhem, T. S. \& Giulietti, A. M. (eds.). Flora fanerogâmica do estado de São Paulo 4: 279-300.

Kurtz, B. C. \& Araújo, D. S. D. 2000. Composição florística e estrutura do componente arbóreo de um trecho de Mata Atlântica na Estação Ecológica Estadual do Paraíso, Cachoeiras de Macacu, Rio de Janeiro, Brasil. Rodriguésia 51(78/115): 69-112.

Lopes, R. C. 1999. Ebenaceae Vent. do estado do Rio de Janeiro. Rodriguésia 50(76/77): 85-107.

Lundell, C. L. 1971. Flora of Panama, Part. VIII. Family 150. Myrsinaceae. Annals of the Missouri Botanical Garden 58: 285-353.

Mayer, S. S. \& Charlesworth, D. 1991. Cryptic dioecy in flowering plants. Trends in Ecology and Evolution 6: 320-325. 
Mez, C. 1902. Myrsinaceae. In: Engler, H. G.

A. Das Pflanzenreich. Berlin, Wilhelm Engelmann, 9 (IV, 236): 1-437.

Miquel, F. A. G. 1856. Myrsineae. In: Martius, C. F. P. von; Eichler, A. G. \& Urban, I. Flora brasiliensis. Munchen, Wien, Leipzig, 10: 269-338.

Oliveira-Filho, A. T. 2006. Catálogo das Árvores de Minas Gerais: mapeamento e inventário da flora nativa e dos reflorestamentos de Minas Gerais. Lavras: Editora UFLA. 423 p.

Pipoly III, J. J. 1989. Notas sobre el género Stylogyne A.DC. (Myrsinaceae). Ernstia 53: $1-9$.

1991. Stylogyne rodriguesiana (Myrsinaceae) A new androdioecious species from Amazonia. Novon 1: 202-203. 1999. Two new species of Myrsinaceae from French Guiana. Brittonia 51(2): 128-133. \& Ricketson, J. M. 1999. Novelties in the Myrsinaceae from the Venezuelan Guyana. Sida 18(4): 1167-1174.

\& Ricketson, J. M. 2000. Stylogyne aguarunana (Myrsinaceae) a new species from Amazonas, Peru. Sida 19(2): 269-273.

Radford, A. E.; Dickinson, W. C.; Massey, J. R. \& Bell C. R. 1974. Vascular plant systematics. Harper \& Row, New York, 891p.

Ribeiro, J. E. L. S.; Hopkins, M. J. G.; Vicentini, A.; Sothers, C. A.; Costa, M. A. S.; Brito, J. M.; Souza, M.A.D.; Martins, L. H. P.; Lohmann, L. G.; Assunção, P. A. C. L.; Pereira, E. C.; Silva, C. F.; Mesquita, M. R. \& Procópio, L. C. 1999. Flora da Reserva Ducke: Guia de identificação das plantas vasculares de uma floresta de terra firme na Amazônia Central. Manaus, INPA, 816p.

Ricketson, J. M. \& Pipoly III, J. J. 1997. Nomenclatural notes and synopsis of Mesoamerican Stylogyne (Myrsinaceae). Sida 17(3): 591-597.

\& Pipoly III, J. J. 2003. A new species of Stylogyne (Myrsinaceae) from Darién, Panamá. Sida 20(3): 919-922.

Ståhl, B. 1996. The relationships of Herbedenia bahamensis and $H$. penduliflora (Myrsinaceae). Botanical Journal of Linnean Society 122: 315-333. 